\title{
Inflammatory bowel disease and pregnancy
}

\author{
Anna M. Maliszewska, Aleksandra Warska, Krzysztof Cendrowski, Włodzimierz Sawicki \\ Chair and Clinic of Obstetrics, Gynecology and Oncology, Second Faculty of Medicine, Medical University of Warsaw, Poland
}

\begin{abstract}
Inflammatory bowel disease (IBD) comprising Crohn's disease (CD), ulcerative colitis (UC), and IBD-unclassified (IBD-U) may appear at any age. As such, IBD commonly affects young patients in their reproductive age. Rate of voluntary childlessness among women with IBD far exceed that of the general population, as patients with IBD fear not only the effect of pregnancy on the course of inflammatory bowel disease, but also the increased risk of the offspring developing the disease, adverse pregnancy outcomes, the effect IBD treatment may have on the health and development of the infant or the risk of relapse during pregnancy and the influence of lactation on child development and disease course. This article aims at improving pre-conception counseling of patients with inflammatory bowel disease.
\end{abstract}

Key words: inflammatory bowel disease, pregnancy, lactation

Ginekologia Polska 2017; 88, 7: 398-403

\section{INTRODUCTION}

Inflammatory bowel disease (IBD) is a group of chronic inflammatory diseases of the gastrointestinal tract including ulcerative colitis (UC), Crohn's disease (CD), and non-specific inflammatory bowel disease.

The incidence of ulcerative colitis among women is $9.8 / 100,000$ with a peak onset at age 25 to 34 years. The incidence of Crohn's disease among women is about $5.0 / 100,000$ with a peak onset at age 15 to 24 [1], which means that the disease affects women mostly in childbearing age.

Ulcerative colitis is an inflammatory disease of the colon, which starts in the rectum and continues proximally up the colon. In about one-fifth to one-third of cases, the entire colon is affected. The inflammatory process affects the mucous membrane only. The disease manifests itself by diarrhea mixed with blood and mucus, abdominal cramping, painful urge for bowel movements and low grade fever. The clinical course includes periods of exacerbation and remission.

Crohn's disease is in turn a segmental inflammation of the digestive tract, which may affect any part of the digestive tract but is most often located in the terminal ileum and proximal colon. The inflammatory process is transmural - it affects all layers of the intestinal wall. Clinical signs include abdominal pain, diarrhea (usually without blood), and bloat- ing. Abdominal pain occurs most often in the right lower quadrant and may be accompanied by a low grade fever. The disease is characterized by periods of clinical exacerbation and remission.

Women who experience inflammatory bowel disease are often concerned about its possible effects on fertility and pregnancy, as well as the inheritance of intestinal disease or developmental defects as side effects of treatment. IBD patients are more likely than the general population to choose to remain childless [2].

\section{INFLUENCE ON FERTILITY}

IBD treatment does not affect fertility. Even though as many as $42.7 \%$ of women with non-specific intestinal inflammation are concerned about infertility according to Mountifield [3], IBD patients in remission who have not undergone pelvic surgery have comparable fertility to that of the general population $[2,4,5]$. Fertility slightly decreases in patients during exacerbation or in patients after surgery involving pelvic inlet like J-pouch ileo-anal anastomosis. The fertility maybe impaired as consequence of tubal adhesions, hydrosalpinx, dysfunction of fimbriae, or fallopian tube obstruction. The adjusted fertility rate ratio for colitis ulcerosa is 0.92 (95\% Cl 0.86-1.00) while it is 0.87 (95\% Cl 0.82-0.94) for Crohn's disease [6]. Lower fertility in CD may be attrib- 
uted to inflammation of the fallopian tubes and ovaries and dyspareunia in cases where the disease affects the perianal area [2]. Şenateş et al. evaluated the ovarian reserve indicator in women of childbearing age with $C D$ and showed that levels of anti-Müllerian hormone in the serum of Crohn's disease patients was lower than in the control group and its concentration is negatively correlated with the disease activity [7].

\section{INFLUENCE OF PREGNANCY ON THE COURSE OF INFLAMMATORY BOWEL DISEASES}

If conception occurs during remission, the risk of relapse does not change. Therefore, patients should be advised to become pregnant at a time of quiescent disease. In contrast, if fertilization occurs during a period of exacerbation, there is a risk of persistent activity or higher rates of relapse during pregnancy [5]. Patients with UC are more likely to develop relapse during pregnancy than patients with $C D$, regardless of age, nicotine use, pre-existing disease activity, previous IBD-associated surgery, immunosuppressive therapy, or TNF therapy [8]. No difference in the course of Crohn's disease was observed between non-pregnant and pregnant women, both during and after childbirth. Risk factors for continuous $C D$ activity during pregnancy are immunosuppressive therapy and longer history of illness. In contrast, ulcerative colitis exacerbations are more likely to occur in pregnant patients (both during pregnancy and after delivery) than in non-pregnant patients. Relapse may occur most often during the first and second trimesters of pregnancy [9]. Overall, pregnancy has a positive effect on the course of IBD. As the birth rate increases, the need for surgical intervention is reduced. In addition, patients with a history of pregnancy less frequently require resection of the intestine while the interval between operations may be longer than for those who have not been pregnant [10]. Over a 10-year observational study, Riis et al. reported a reduction in rate of exacerbations of $C U$ and $C D$ in the years following pregnancy [11].

\section{INFLUENCE ON THE COURSE OF PREGNANCY}

Women suffering from inflammatory bowel disease have an increased risk of adverse pregnancy outcomes. IBD is associated with premature delivery, low birth weight, and small for gestational age birth. An increased rate of both elective and emergency cesarean sections is also observed $[12,13]$. An important risk factor for complications during pregnancy is the activity of inflammatory bowel disease at the time of conception and during pregnancy [14]. Previous infertility treatment increases the risk of miscarriage. History of intestinal surgery is an independent risk factor for low birth weight or cesarean delivery [15]. Mahadevan et al. performed a cohort study comparing obstetric outcomes in IBD and IBD-free patients. The proportion of live births was $60 \%$ in patients with IBD and $68 \%$ in patients without intestinal inflammatory disease. Miscarriages occurred more often in the IBD group (in $23 \%$ of cases versus $17 \%$ for the control group), as did adverse pregnancy outcomes such as low birth weight, premature birth and stillbirths (25\% vs. $19 \%)$. The risk of miscarriage increases in IBD patients who have undergone bowel surgery. Pregnancy complications such as placental abruption, chorioamnionitis, premature rupture of membranes, preeclampsia, eclampsia, fetal distress, infection, maternal blood transfusion, placenta previa and urine group B streptococcus infection were more common in patients with IBD ( $25 \%$ vs. $16 \%)$. There was no statistically significant difference between the studied groups in terms of adverse neonatal events such as the need for intensive neonatal care or newborn death (10\% vs. $7 \%$ ) [16].

Similarly, Lin et al. showed a higher premature birth rate $(11.73 \%$ vs. $6.25 \%)$ and a lower neonatal birth weight $(12.76 \%$ vs. $5.55 \%)$ in mothers with colitis ulcerosa as compared to those without the disease [17]. Stephansson et al. evaluated the impact of ulcerative colitis on pregnancy and found the risk of premature delivery, caesarean section, neonatal death and low birth weight to be increased. The risk of pregnancy complications was higher in women who had undergone CD-related surgery or had a history of hospitalization. The authors did not report an increased risk of congenital abnormalities in the fetus [18].

Morales et al. studied the effects of CD on the course of pregnancy and reported that the disease exacerbation was associated with an increased risk of premature labor, while conception during exacerbation was associated with an increased risk of miscarriage. The relapse rate during pregnancy was comparable to that of the non-pregnant CD population [19]. Similarly, Stephansson study found similar results showing an increased risk of premature labor and caesarean section, as well as a slightly increased risk of small for gestational age birth. The authors did not report an increase in the risk of preeclampsia, low 5-minute Apgar score, stillbirth or congenital malformations [20].

\section{MODE OF DELIVERY}

The mode of delivery should take into account obstetric indications primarily. The gastroenterologist or colorectal surgeon should help in assessing the impact of postpartum sphincter/pelvic floor dysfunction on current and future bowel function. A caesarean section is recommended for patients with active disease localized in the perineal area or involving the rectum [2]. Episiotomy, if possible, should be avoided since it often leads to development of the disease in the perineal area. Yet, it is preferable to uncontrolled rupture of tissues [21]. Compared to patients delivering by caesarean section, the risk of developing the disease de novo 
in the perineal area after vaginal birth does not increase. The disease progression is also less frequent in patients who have had previously a localized disease in the perineal area and gave birth vaginally [22]. Interestingly, in a study of Norton et al. based on a sample of 2178 patients no correlation between vaginal birth and fecal incontinence was found [23]. The presence of ileal pouch-anal anastomosis remains a relative indication for caesarean section [24]. If not contraindicated for other reasons, patients with colostomy or ileostomy may deliver vaginally.

\section{HEREDITY}

The strongest predictor of developing IBD is family history. If one parent is affected, the risk of IBD development in offspring is $1.6 \%$ for UC and $5.2 \%$ for CD. If both parents are diagnosed with IBD, the lifetime risk of developing the disease in offspring is estimated at 36\% [16]. In case of Crohn's disease, the risk increase is significant if the affected parent is the mother and the offspring is female [25].

\section{CONGENITAL MALFORMATIONS}

The risk of congenital abnormalities in the offspring of women suffering from inflammatory bowel disease is the same as in the general population $[15,18,20]$. In the aforementioned Mahadevan study, the authors did not observe a difference in the congenital malformation rate between women with colitis ulcerosa and Crohn's disease [16]. Among the drugs that may be used to treat IBD, methotrexate and thalidomide are teratogenic and absolutely contraindicated during pregnancy. When it comes to the safety of thiopurine and corticosteroid therapy during the first trimester, the results remain ambiguous [2]. Ban et al. analyzed the incidence of congenital anomalies in children born in the United Kingdom between 1990 and 2010 and showed that maternal inflammatory bowel disease and related therapies did not increase the risk of serious congenital abnormalities [26]. Similarly, the study of Wozniak et al. on Polish population found no impact of IBD on the frequency of congenital anomalies [27].

\section{POSTPARTUM PERIOD}

Discontinuing medication may lead to exacerbation of the disease. The risk of recurrence in CD patients on maintenance therapy is not increased during the postpartum period, although it may increase in women with ulcerative colitis. UC exacerbation usually occurs within 3 months after delivery [5]. $71 \%$ of CD patients and $60 \%$ of UC patients remain in remission during the postpartum period, compared to $78 \%$ and $81 \%$ of patients in the control group, respectively. For $C D$ patients, more than five years history of disease is a risk factor for a recurrence in the postpartum period [9]. After the pregnancy, function of J-Pouch remains unchanged [24].

\section{LACTATION}

The percentage of women with inflammatory bowel disease who breast-feed varies from $44.2 \%$ to $83.3 \%$ [28, 29]. Breastfeeding is not associated with increased risk of disease exacerbation. On the contrary, it may protect against relapse in the year following birth, suggested by some studies $[28,30]$. The risk of relapse in the first year after birth for breastfeeding mothers was $26 \%$ versus $29.4 \%$ for non-breastfeeding mothers with CD and $29.2 \%$ versus $44.4 \%$ for UC patients, respectively [28]. There are some premises that breast-feeding can be protective with respect to early-onset IBD in the offspring [30].

\section{TREATMENT}

It is usually the gastroenterologists that treat IBD. Basic information on treatment during pregnancy and postpartum period is summarized in Tables 1 and 2 [30-36]. Sulfasalazine treatment affects folate absorption, therefore patients taking sulfasalazine are advised to supplement higher doses of folic acid ( $2 \mathrm{mg} /$ day).

\section{SUMMARY}

Inflammatory bowel disease affects a large group of women of childbearing age. Patients expect guidelines from gynecologists on how to prepare themselves for pregnancy, as well as information on whether the disease affects fertility, the course of pregnancy, whether there is a risk of congenital defects associated with inflammation of the bowel or treatment thereof, or whether children may inherit the disease. Additionally, information on the influence of pregnancy and lactation on the course of the disease is essential for making fully conscious decisions regarding pregnancy and lactation. Access to factual information reduces the concerns of patients, reducing the proportion of voluntary childless patients. 
Table 1. Therapy during pregnancy

\begin{tabular}{|c|c|c|}
\hline Drugs & Use in pregnancy & Influence on pregnancy \\
\hline \multicolumn{3}{|l|}{ 5-ASA } \\
\hline Mesalamine & $\begin{array}{l}\text { Category B } \\
\text { Possible to apply } \\
\text { Low risk }\end{array}$ & $\begin{array}{l}\text { Does not increase the risk of stillbirth, congenital anomalies, preterm } \\
\text { delivery, spontaneous abortion or low birth weight }\end{array}$ \\
\hline $\begin{array}{l}\text { Asacol } \\
\text { (formulations containing } \\
\text { dibutyl phthalate) }\end{array}$ & $\begin{array}{l}\text { Category C } \\
\text { Possible to apply } \\
\text { Low risk }\end{array}$ & $\begin{array}{l}\text { In animal studies, it causes urinary tract and skeletal system defects } \\
\text { Recommended to change to mesalamine }\end{array}$ \\
\hline Sulfsalazine & $\begin{array}{l}\text { Category B } \\
\text { Possible to apply } \\
\text { Low risk }\end{array}$ & $\begin{array}{l}\text { Crosses placental barrier } \\
\text { Inhibits the absorption and metabolism of folic acid } \\
\text { Supplementation up to } 2 \mathrm{mg} \text { per day of folic acid is recommended during } \\
\text { preconception period and pregnancy to prevent neural tube defects }\end{array}$ \\
\hline \multicolumn{3}{|l|}{ Antibiotics } \\
\hline Metronidazole & $\begin{array}{l}\text { Category B } \\
\text { Do not use in the first trimester } \\
\text { Low risk with short term use }\end{array}$ & $\begin{array}{l}\text { Crosses placental barrier } \\
\text { Single reports of teratogenicity, yet unconfirmed in studies both in } \\
\text { humans and animals }\end{array}$ \\
\hline Ciprofloxacin & $\begin{array}{l}\text { Category C } \\
\text { Do not use in the first trimester } \\
\text { Low risk with short term use }\end{array}$ & $\begin{array}{l}\text { Crosses the placenta } \\
\text { In animal studies it affects bones and cartilage causing potentially arthritis } \\
\text { Unconfirmed in human studies }\end{array}$ \\
\hline \multicolumn{3}{|l|}{ Corticosteroids } \\
\hline Prednisolone & $\begin{array}{l}\text { Category } C \\
\text { Recommended low doses } \\
\text { Low risk }\end{array}$ & $\begin{array}{l}\text { Crosses the placenta } \\
\text { Increased risk of SGA, gestational diabetes, early neonatal infection } \\
\text { Single reports of increased incidence of cleft palate, ultimately unconfirmed }\end{array}$ \\
\hline Budesonide & $\begin{array}{l}\text { Category } B / C \\
\text { Recommended low doses } \\
\text { Low risk }\end{array}$ & $\begin{array}{l}\text { Crosses the placenta } \\
\text { High first-pass metabolism and less side effects }\end{array}$ \\
\hline \multicolumn{3}{|l|}{ Immunomodulators } \\
\hline Thiopurines & $\begin{array}{l}\text { Category D } \\
\text { It is not recommended to start treatment } \\
\text { during pregnancy because of side effects } \\
\text { such as pancreatitis or leukopenia } \\
\text { Low risk }\end{array}$ & $\begin{array}{l}\text { Single reports of an increased incidence of preterm delivery and } \\
\text { congenital ventricular and atrial septal defects }\end{array}$ \\
\hline Cyclosporine & $\begin{array}{l}\text { Category C } \\
\text { Low risk }\end{array}$ & $\begin{array}{l}\text { Crosses the placenta } \\
\text { Possible toxic effects }\end{array}$ \\
\hline Tacrolimus & $\begin{array}{l}\text { Category C } \\
\text { Low risk }\end{array}$ & $\begin{array}{l}\text { Crosses the placenta } \\
\text { May cause hyperkalemia and renal dysfunctions }\end{array}$ \\
\hline Methotrexate & $\begin{array}{l}\text { Category } X \\
\text { Contraindicated } \\
\text { Stop optimally } 3 \text { months before fertilization } \\
\text { in men and } 6 \text { months in female }\end{array}$ & $\begin{array}{l}\text { Crosses the placenta } \\
\text { Teratogenic effects } \\
\text { May lead to fetal death }\end{array}$ \\
\hline \multicolumn{3}{|c|}{$\begin{array}{l}\text { Anti-TNF agents } \\
\text { They may cause decreased immunity, therefore live vaccines should be avoided during the first } 6-12 \text { months of life of the newborn } \\
\text { exposed in utero }\end{array}$} \\
\hline Adalimumab & $\begin{array}{l}\text { Category B } \\
\text { Recommended to stop in third trimester } \\
\text { Low risk }\end{array}$ & $\begin{array}{l}\text { Crosses the placenta } \\
\text { Does not increase the risk of birth defects, premature births, stillbirths, } \\
\text { miscarriages or SGA }\end{array}$ \\
\hline Certolizumab & $\begin{array}{l}\text { Category B } \\
\text { Can continue during pregnancy } \\
\text { Low risk }\end{array}$ & $\begin{array}{l}\text { Minimally crosses the placenta } \\
\text { Does not increase the risk of premature labor or neonatal infection }\end{array}$ \\
\hline Infliximab & $\begin{array}{l}\text { Category B } \\
\text { Recommended to stop in third trimester } \\
\text { Low risk }\end{array}$ & $\begin{array}{l}\text { Crosses the placenta } \\
\text { Does not increase the risk of preterm delivery or neonatal infection }\end{array}$ \\
\hline Golimumab & $\begin{array}{l}\text { Category B } \\
\text { Recommended to stop in third trimester } \\
\text { Low risk }\end{array}$ & Crosses the placenta \\
\hline
\end{tabular}


Table 1 (cont.). Therapy during pregnancy

\begin{tabular}{l|l|l|}
\hline Drugs & Use in pregnancy & Influence on pregnancy \\
\hline Anti-integrins & $\begin{array}{l}\text { Category C } \\
\text { Limited human data } \\
\text { Recommended to stop 3 months before } \\
\text { pregnancy }\end{array}$ & $\begin{array}{l}\text { Possible placental transfer } \\
\text { Increases the risk of spontaneous abortion }\end{array}$ \\
\hline Vedolizumab & $\begin{array}{l}\text { Category B } \\
\text { Limited human data }\end{array}$ & Possible placental transfer \\
\hline Anti-IL-12/23 drugs & Limited human data & \\
\hline Ustekinumab & &
\end{tabular}

Table 2. Therapy during lactation

\begin{tabular}{|c|c|c|}
\hline Drugs & Influence on lactation & Additional impact \\
\hline \multicolumn{3}{|c|}{$\begin{array}{l}\text { 5-ASA } \\
\text { Increases levels of free bilirubin, potentially leading to kernicterus }\end{array}$} \\
\hline Mesalamine & Low risk & Single cases of neonatal diarrhea \\
\hline Asacol & Low risk & \\
\hline Sulfsalazine & Low risk & \\
\hline \multicolumn{3}{|l|}{ Antibiotics } \\
\hline Metronidazole & $\begin{array}{l}\text { Avoid prolonged course of treatment } \\
\text { Breastfeeding after } 12-24 \mathrm{~h}\end{array}$ & Potential toxicity in the infant due to prolonged course of treatment \\
\hline Ciprofloxacin & $\begin{array}{l}\text { Avoid prolonged course of treatment } \\
\text { Breastfeeding after } 48 \mathrm{~h}\end{array}$ & Prolonged course of treatment may result in neonatal arthropathies \\
\hline \multicolumn{3}{|l|}{ Corticosteroids } \\
\hline Prednisolone & $\begin{array}{l}\text { Low risk } \\
\text { Breastfeeding after } 4 \mathrm{~h}\end{array}$ & \\
\hline Budesonide & Low risk & \\
\hline \multicolumn{3}{|c|}{ Immunomodulators } \\
\hline Thiopurines & $\begin{array}{l}\text { Low risk } \\
\text { Breastfeeding after } 4 \mathrm{~h}\end{array}$ & \\
\hline Cyclosporine & $\begin{array}{l}\text { Contraindicated } \\
\text { High concentration in breast milk }\end{array}$ & $\begin{array}{l}\text { Potential immunosuppressive effect } \\
\text { Toxicity }\end{array}$ \\
\hline Tacrolimus & Low risk & Single reports on safety in use \\
\hline Methotrexate & $\begin{array}{l}\text { Contraindicated } \\
\text { High concentration in breast milk }\end{array}$ & Toxicity \\
\hline Anti-TNF drugs & Limited data & $\begin{array}{l}\text { Low concentrations in breast milk and poor absorption lead to } \\
\text { subtherapeutic concentrations in the neonate's blood }\end{array}$ \\
\hline Adalimumab & Low risk & \\
\hline Certolizumab & Low risk & Undetectable in breast milk \\
\hline Infliximab & Low risk & \\
\hline Golimumab & Limited data, low risk & \\
\hline \multicolumn{3}{|l|}{ Anti-integrins } \\
\hline Natalizumab & Limited data & \\
\hline Vedolizumab & Limited data & \\
\hline \multicolumn{3}{|c|}{ Anti-IL-12/23 drugs } \\
\hline Ustekinumab & Limited data & \\
\hline
\end{tabular}




\section{REFERENCES}

1. Shivananda S, Lennard-Jones J, Logan R, et al. Incidence of inflammatory bowel disease across Europe: is there a difference between north and south? Results of the European Collaborative Study on Inflammatory Bowel Disease (EC-IBD). Gut. 1996; 39(5): 690-697, indexed in Pubmed: 9014768.

2. van der Woude CJ, Ardizzone S, Bengtson MB, et al. European Crohn's and Colitis Organization. The second European evidenced-based consensus on reproduction and pregnancy in inflammatory bowel disease. J Crohns Colitis. 2015; 9(2): 107-124, doi: 10.1093/ecco-jcc/jju006, indexed in Pubmed: 25602023.

3. Magro F, Gionchetti P, Eliakim R, et al. European Crohn's and Colitis Organisation [ECCO]. Third European Evidence-based Consensus on Diagnosis and Management of Ulcerative Colitis. Part 1: Definitions, Diagnosis, Extra-intestinal Manifestations, Pregnancy, Cancer Surveillance, Surgery, and Ileo-anal Pouch Disorders. J Crohns Colitis. 2017; 11(6): 649-670, doi: 10.1093/ecco-jcc/jjx008, indexed in Pubmed: 28158501.

4. Hashash JG, Kane S. Pregnancy and Inflammatory Bowel Disease. Gastroenterol Hepatol (NY). 2015; 11 (2): 96-102, indexed in Pubmed: 27099578.

5. Mountifield R, Bampton P, Prosser R, et al. Fear and fertility in inflammatory bowel disease: a mismatch of perception and reality affects family planning decisions. Inflamm Bowel Dis. 2009; 15(5): 720-725, doi: 10.1002/ibd.20839, indexed in Pubmed: 19067431.

6. Ban L, Tata LJ, Humes DJ, et al. Decreased fertility rates in 9639 women diagnosed with inflammatory bowel disease: a United Kingdom population-based cohort study. Aliment Pharmacol Ther. 2015; 42(7): 855-866, doi: 10.1111/apt.13354, indexed in Pubmed: 26250873.

7. Şenateş E, Çolak Y, Erdem ED, et al. Serum anti-Müllerian hormone levels are lower in reproductive-age women with Crohn's disease compared to healthy control women. J Crohns Colitis. 2013; 7(2): e29-e34, doi: 10.1016/j.crohns.2012.03.003, indexed in Pubmed: 22472089.

8. de Lima-Karagiannis A, Zelinkova-Detkova Z, van der Woude CJ. The Effects of Active IBD During Pregnancy in the Era of Novel IBD Therapies. Am J Gastroenterol. 2016; 111(9): 1305-1312, doi: 10.1038/ajg.2016.254, indexed in Pubmed: 27349339.

9. Pedersen N, Bortoli A, Duricova D, et al. European Crohn-Colitis Organisation-ECCO-Study Group of Epidemiology Committee-EpiCom. The course of inflammatory bowel disease during pregnancy and postpartum: a prospective European ECCO-EpiCom Study of 209 pregnant women. Aliment Pharmacol Ther. 2013; 38(5): 501-512, doi: 10.1111/apt.12412, indexed in Pubmed: 23855425.

10. Castiglione F, Pignata S, Morace F, et al. Effect of pregnancy on the clinical course of a cohort of women with inflammatory bowel disease. Ital J Gastroenterol. 1996; 28(4): 199-204, indexed in Pubmed: 8842834.

11. Riis L, Vind I, Politi P, et al. European Collaborative study group on Inflammatory Bowel Disease. Does pregnancy change the disease course? A study in a European cohort of patients with inflammatory bowel disease. Am J Gastroenterol. 2006; 101(7): 1539-1545, doi: 10.1111/j.1572-0241.2006.00602.x, indexed in Pubmed: 16863558.

12. Raatikainen $\mathrm{K}$, Mustonen J, Pajala MO, et al. The effects of pre- and post-pregnancy inflammatory bowel disease diagnosis on birth outcomes. Aliment Pharmacol Ther. 2011; 33(3): 333-339, doi: 10.1111/j.1365-2036.2010.04538.x, indexed in Pubmed: 21138456.

13. Molnár T, Farkas K, Nagy F, et al. Pregnancy outcome in patients with inflammatory bowel disease according to the activity of the disease and the medical treatment: a case-control study. Scand J Gastroenterol. 2010; 45(11): 1302-1306, doi: 10.3109/00365521.2010.503967, indexed in Pubmed: 20602569.

14. Oron $G$, Yogev $Y$, Shcolnick $S$, et al. Inflammatory bowel disease: risk factors for adverse pregnancy outcome and the impact of maternal weight gain. J Matern Fetal Neonatal Med. 2012; 25(11): 2256-2260, doi: 10.3109/14767058.2012.684176, indexed in Pubmed: 22524421.

15. Naganuma M, Kunisaki R, Yoshimura N, et al. Conception and pregnancy outcome in women with inflammatory bowel disease: A multicentre study from Japan. J Crohns Colitis. 2011; 5(4): 317-323, doi: 10.1016/j. crohns.2011.02.003, indexed in Pubmed: 21683301.

16. Mahadevan U, Sandborn WJ, Li DK, et al. Pregnancy outcomes in women with inflammatory bowel disease: a large community-based study from Northern California. Gastroenterology. 2007; 133(4): 1106-1112, doi: 10.1053/j.gastro.2007.07.019, indexed in Pubmed: 17764676.

17. Lin HC, Chiu CCJ, Chen SF, et al. Ulcerative colitis and pregnancy outcomes in an Asian population. Am J Gastroenterol. 2010; 105(2): 387-394, doi: 10.1038/ajg.2009.562, indexed in Pubmed: 19809415.
18. Stephansson $\mathrm{O}$, Larsson $\mathrm{H}$, Pedersen $\mathrm{L}$, et al. Congenital abnormalities and other birth outcomes in children born to women with ulcerative colitis in Denmark and Sweden. Inflamm Bowel Dis. 2011; 17(3): 795-801, doi: 10.1002/ibd.21369, indexed in Pubmed: 20564537.

19. Morales M, Berney T, Jenny A, et al. Crohn's disease as a risk factor for the outcome of pregnancy. Hepatogastroenterology. 2000; 47(36): 1595-1598, indexed in Pubmed: 11149010.

20. Stephansson O, Larsson $\mathrm{H}$, Pedersen $\mathrm{L}$, et al. Crohn's disease is a risk factor for preterm birth. Clin Gastroenterol Hepatol. 2010; 8(6): 509-515, doi: 10.1016/j.cgh.2010.02.014, indexed in Pubmed: 20202483.

21. Brandt LJ, Estabrook SG, Reinus JF. Results of a survey to evaluate whether vaginal delivery and episiotomy lead to perineal involvement in women with Crohn's disease. Am J Gastroenterol. 1995; 90(11): 1918-1922, indexed in Pubmed: 7484992.

22. Smink M, Lotgering FK, Albers $L$, et al. Effect of childbirth on the course of Crohn's disease; results from a retrospective cohort study in the $\mathrm{Ne}$ therlands. BMC Gastroenterol. 2011; 11:6, doi: 10.1186/1471-230X-11-6, indexed in Pubmed: 21269464.

23. Norton C, Dibley LB, Bassett P. Faecal incontinence in inflammatory bowel disease: associations and effect on quality of life. J Crohns Colitis. 2013; 7(8): e302-e311, doi: 10.1016/j.crohns.2012.11.004, indexed in Pubmed: 23228710.

24. Hahnloser D, Pemberton JH, Wolff BG, et al. Pregnancy and delivery before and after ileal pouch-anal anastomosis for inflammatory bowel disease: immediate and long-term consequences and outcomes. Dis Colon Rectum. 2004; 47(7): 1127-1135, doi: 10.1007/s10350-004-0569-0, indexed in Pubmed: 15164253.

25. Zelinkova Z, Stokkers PC, van der Linde K, et al. Maternal imprinting and female predominance in familial Crohn's disease. J Crohns Colitis. 2012; 6(7): 771-776, doi: 10.1016/j.crohns.2012.01.002, indexed in Pubmed: 22398090

26. Ban Lu, Tata LJ, Fiaschi L, et al. Limited risks of major congenital anomalies in children of mothers with IBD and effects of medications. Gastroenterology. 2014; 146(1): 76-84, doi: 10.1053/j.gastro.2013.09.061, indexed in Pubmed: 24126096.

27. Wozniak P, Brucka-Kaczor A, Litwinska E, et al. Perinatal outcome in women with inflammatory bowel disease. Ginekol Pol. 2015 ; 86(5): 376-382, doi: 10.17772/gp/2426.

28. Moffatt DC, Inyckyj A, Bernstein CN. A population-based study of breastfeeding in inflammatory bowel disease: initiation, duration, and effect on disease in the postpartum period. Am J Gastroenterol. 2009; 104(10): 2517-2523, doi: 10.1038/ajg.2009.362, indexed in Pubmed: 19550409.

29. Kane S, Lemieux $N$. The role of breastfeeding in postpartum disease activity in women with inflammatory bowel disease. Am J Gastroenterol. 2005; 100(1): 102-105, doi: 10.1111/j.1572-0241.2005.40785.x, indexed in Pubmed: 15654788.

30. Nguyen GC, Seow CH, Maxwell C, et al. IBD in Pregnancy Consensus Group, Canadian Association of Gastroenterology. The Toronto Consensus Statements for the Management of Inflammatory Bowel Disease in Pregnancy. Gastroenterology. 2016; 150(3): 734-757.e1, doi: 10.1053/j. gastro.2015.12.003, indexed in Pubmed: 26688268.

31. Damas OM, Deshpande AR, Avalos DJ, et al. Treating Inflammatory Bowel Disease in Pregnancy: The Issues We Face Today. J Crohns Colitis. 2015; 9(10): 928-936, doi: 10.1093/ecco-jcc/jjv118, indexed in Pubmed: 26129693.

32. Gaidos JKJ, Kane SV. Managing IBD Therapies in Pregnancy. Curr Treat Options Gastroenterol. 2017; 15(1): 71-83, doi: 10.1007/s11938-0170123-5, indexed in Pubmed: 28181180.

33. Niebyl JR. Antibiotics and other anti-infective agents in pregnancy and lactation. Am J Perinatol. 2003; 20(8): 405-414, doi: 10.1055/s-200345391, indexed in Pubmed: 14703588.

34. Lin K, Martin C, Dassopoulos T, et al. 2 Pregnancy Outcomes Amongst Mothers With Inflammatory Bowel Disease Exposed to Systemic Corticosteroids: Results of the PIANO Registry. Gastroenterology. 2014; 146(5): S-1, doi: 10.1016/s0016-5085(14)60002-0.

35. Cleary BJ, Källén B. Early pregnancy azathioprine use and pregnancy outcomes. Birth Defects Res A Clin Mol Teratol. 2009; 85(7): 647-654, doi: 10.1002/bdra.20583, indexed in Pubmed: 19343728.

36. Mahadevan U, Martin C, Dubinsky M, et al. 960 Exposure to Anti-TNFa Therapy in the Third Trimester of Pregnancy Is Not Associated With Increased Adverse Outcomes: Results From the PIANO Registry. Gastroenterology. 2014; 146(5): S-170, doi: 10.1016/s0016-5085(14)60602-8. 